\title{
Development of consumer probiotics for the US market
}

\author{
Mary E. Sanders \\ Dairy and Food Culture Technologies, Littleton, CO 80122, USA and California Polytechnic State University, San Luis \\ Obispo, CA 93407, USA
}

\begin{abstract}
Curiosity about probiotic bacteria is high. This is not surprising given the rapid growth of the natural products market in the USA, which was $22 \%$ in 1995 (New Hope Natural Media, Boulder, $\mathrm{CO}$ ). Although probiotic cultures are only one component of that market, this trend shows that consumers in the USA are increasingly taking a pro-active stance towards their health and are purchasing products not only to eliminate what is perceived as dietary negatives but to increase the levels of dietary positives (Wrick, 1995). This shift in consumer attitude bodes well for the development of the American probiotic market. This article describes the composition, promotion and labelling of probiotic-containing products, discusses attributes of commercial probiotic bacteria, and estimates the size of the probiotic market in the USA. This market information was obtained from several published (Anon, 1996a,b) and unpublished but commercially available (SPINS Information Services, San Francisco, CA and New Hope Natural Media, Boulder, CO) sources.
\end{abstract}

Probiotic: Lactobacilli: Functional foods

\section{American probiotic products}

In the American market, probiotic bacteria are sold in two different formats: food and dietary supplements. The food products containing probiotic bacteria are almost exclusively dairy products, capitalizing on the historical association of lactic acid bacteria with fermented milk. Probiotic bacteria used in these products include Lactobacillus acidophilus and Bifidobacterium species. The dairy products associated with probiotic bacteria are primarily probioticadded fluid milk and yoghurt. Table 1 lists fluid milk products in the USA and shows that a mere $0.6 \%$ contains probiotic bacteria. These products utilize approximately $40 \%$ of the probiotic bacteria desired for use in dairy products. In contrast, most major, and many minor, brands of yoghurt contain probiotic bacteria, accounting for the remaining $60 \%$ of dairy-destined probiotic bacteria.

Fluid milk containing probiotics (unfermented acidophilus milks) became a feasible product concept when bacterial concentration technology improved and led to the commercial production of frozen culture concentrates. These milks were conceived by Paul Elliker at Oregon State University in the 1950 s and were first marketed in the USA in the 1970 s as Sweet Acidophilus ${ }^{\text {TM }}$ milk, a product containing the Lactobacillus acidophilus $\mathrm{NCFM}^{\mathrm{TM}}$ strain that was developed at North Carolina State University. That product enjoyed regional success in the southeastern states of America, partly due to successful promotional campaigns.

Another commercial application of probiotics is a kefirtype drink developed by GalaGen Inc. (Arden Hills, MN) and Lifeway Foods (Skokie, IL) called Basic Plus. It is a fruit-flavoured drink marketed as a dietary supplement formulated with probiotic-containing lactic cultures
(L. casei subspecies casei, L. plantarum, Lactococcus lactis, and Lueuconostoc mesenteroides subspecies cremoris) and immunoglobulins from the colostrum of cows (Gorski, 1998). The polyclonal antibodies isolated from the colostrum are thought to provide passive immunity, thereby increasing resistance to infection, a claim supported by a variety of scientific studies including those by Greenberg \& Cello (1996) and Stephan et al. (1990). This product is intended to support the body's natural microflora and to maintain gastrointestinal health. Initial test markets are in the Midwestern states and eastern Europe.

Another example of new product development using probiotic bacteria is by ConAgra, the second largest food company in the USA. An agreement with Valio Dairies to develop a line of functional food products including the probiotic strain Lactobacillus rhamnosus GG was recently announced (Anon, 1997). The company plans to test market products in late 1998 .

New food product developments in the probiotic area have not always succeeded in the USA. Earlier this decade, Land O'Lakes (Minneapolis, MN) marketed an orange juice product which contained vitamin E, L. acidophilus and Bifidobacterium cultures as part of their Plus 3 product line. According to a representative of Land O'Lakes, although the Plus 3 milk-based products were strong products, the Plus 3 juice product was eliminated due to poor sales (Bill Aimutis, personal communication).

Strategies for formulation of American dairy products with probiotic bacteria are largely left up to the manufacturer. The American standard of identity for yoghurt requires fermentation with at least Lactobacillus bulgaricus and Streptococcus thermophilus, but no levels are specified. California and Oregon are the only states 
Table 1. Fluid milk product distribution in the USA (Anon, 1996b)

\begin{tabular}{lc}
\hline Milk type & Market share (\%) \\
\hline Whole milk & 30 \\
Reduced fat (2\% fat) milk & 35 \\
Low fat (1\% fat) milk & 13 \\
Fat-free (skimmed) milk & 18 \\
Flavoured milk & 1.6 \\
Buttermilk & 1.1 \\
Cultures-added ('acidophilus milk') milk & 0.6 \\
Reduced lactose milk & 0.6 \\
Shelf stable (UHT) milk & 0.1 \\
\hline
\end{tabular}

requiring minimum levels of probiotic bacteria in any dairy product: $2 \times 10^{6} \mathrm{cfu} / \mathrm{ml}$ are required in unfermented 'acidophilus milk'. Culture manufacturers recommend approximately $10^{6}$ probiotic bacteria per gram for yoghurt and unfermented acidophilus milk at the end of shelf-life, but viable counts may fall below these levels. A survey of commercial yoghurts in Australia found that among fifty commercial yoghurts, viable populations of Lactobacillus delbrueckii ssp. bulgaricus and $S$. thermophilus exceeded $10^{7} \mathrm{cfu} / \mathrm{g}$ in $54 \%$ and $68 \%$ of the samples, respectively. The viable populations of $L$. acidophilus and Bifidobacterium species exceeded $10^{6} \mathrm{cfu} / \mathrm{g}$ in $24 \%$ and $14 \%$ of the samples, respectively (Rybka \& Fleet, 1997).

The National Yogurt Association (McLean, VA) established a 'Live active culture' seal that helps consumers to recognize yoghurt containing live, active cultures for use by any yoghurt manufacturer on packaging. Use of the seal requires refrigerated yoghurt to contain $10^{8}$ viable lactic acid bacteria per gram at time of manufacture. The seal can also be used on frozen yoghurts containing $10^{7}$ viable lactic acid bacteria per gram at time of manufacture. However, these counts do not differentiate probiotic bacteria from starter culture bacteria ( $L$. delbrueckii ssp. bulgaricus and $S$. thermophilus), and therefore are not reflective of probiotic content.

Even if high numbers of probiotic bacteria are present in dairy products, the selective enumeration of probiotic bacteria in a background of starter bacteria is not a trivial undertaking. This can influence the regulator's ability to establish standards for probiotic content and the food company's ability to develop quality assurance methods for products with multiple strains, species and genera. Rapid, selective methods that accurately enumerate and differentiate among different species of the same genera (e.g. $L$. delbrueckii subspecies bulgaricus and $L$. acidophilus) or even different genera (Bifidobacterium. Streptococcus and Lactobacillus) are not always effective with all strains, although several methods have been published (Onggo \& Fleet, 1994; Charteris et al. 1997; Salvadori, 1997; Shah, 1997). The mixture of strains and species in the product and the presence of sublethally injured cells can complicate enumeration. Survival of probiotic bacteria in dairy products is another concern. Although quite stable over the shelf-life in fluid milk (Sanders et al. 1996), probiotic bacteria tend to decline in numbers in yoghurt due to acid or oxygen sensitivity (Klaver, et al. 1993; Dave \& Shah, $1997 a, b, c$; Kailasapathy \& Rybka, 1997). These factors translate into inadequate
Table 2. Bases of differentiation of probiotic-containing products

Probiotic strain
Strain blends
Viable count and stability
Dietary supplement format: capsule, powder, liquid, tablet
Food format: milk, yoghurt, others
Addition of other ingredients to preparation: milk products, dairy-free
carriers, goat milk powder, cranberry extracts,
fructo-oligosaccharides, immunoglobulins, fermentation
byproducts, other 'bioactive ingredients'

communication of viable probiotic bacteria content to the American consumer.

The dietary supplement market for probiotic cultures seems to be a more diverse and more active market than probiotics for the dairy market. The supplement market contains many different product formats and contents (Table 2). A diverse array of bacterial genera and species are represented in these products, including numerous types of lactobacilli, bifidobacteria and less commonly Enterococcus, Bacillus, Escherichia coli and yeast. Dietary supplement products are purchased primarily in health food or natural foods shops. This market has shown a steady increase over the past few years, coincident with the overall upward trend in the natural products market.

Although clinical efficacy is not the subject matter of this article, it is relevant to the discussion of the daily dose of probiotic bacteria delivered to Americans opting to consume currently available probiotic-containing products. Many studies of probiotic bacteria on physiological effects such as diarrhoea, lactose intolerance, activity of faecal enzymes (thought to play a role in colon cancer) and others, typically show an effect using a daily dose of about $10^{9}-$ $10^{10}$ organisms per day (Sanders, 1996). In order to consume $2 \times 10^{9}$ organisms from an acidophilus milk product that is formulated at $2 \times 10^{6} \mathrm{cfu} / \mathrm{ml}$, a litre of milk per day would need to be consumed. Currently, it would be easier to get this level of bacteria in a dietary supplement format, assuming the cells are viable at the time of consumption. Although there is a need for product developers to address delivery of appropriate levels of these organisms, a paucity of pharmacological data on required doses for specific effects in a predominantly healthy population makes this a difficult task.

One additional marketing approach for probiotics is biotherapeutics. Not widely available in the USA, some probiotic products are designed to be recommended by doctors and to relieve specific maladies (not to "promote health'). One such product being tested contains the yeast, Saccharomyces boulardii, and is targeted for treatment of Clostridium difficile pseudomembranous colitis (McFarland \& Elmer, 1997). Non-prescription products have also been used to help restore the normal vaginal microbiota by women prone to vaginal infections (Hughes \& Hillier, 1990).

\section{Size of the American probiotic market}

Industry-wide probiotic sales figures are difficult to document. Three approaches have been used to measure market 
Table 3. American market (1995) for foods and functional foods (Anon, 1996a)

\begin{tabular}{ll}
\hline Segment & Total market \\
\hline Retail food & $\$ 426$ billion \\
Food service & $\$ 204$ billion \\
Drugs/over-the-counter medications & $\$ 98$ billion \\
Nutraceuticals & $\$ 80$ billion \\
Probiotics & Unknown (see text for estimates) \\
Vitamins and supplements & $\$ 6$ billion \\
\hline
\end{tabular}

- Nutraceuticals are defined (Anon, 1996a) as 'healthy consumables': isolated nutrients and dietary supplements, functional foods, market standard foods (foods designed for a health effect that have reached greater than $50 \%$ of market category (e.g. iodized salt), 'lesser evil' (e.g. fat free) foods, natural foods and medical foods.

size: probiotic culture manufacturer information, distributor data and retail surveys. All have flaws, and not all participants are willing to share information or may not provide complete or accurate information. It is best to remember some issues about the probiotic market before delving into available numbers:

(1) 'Marketing figures may be hazy...' is the understatement made in the Nutrition Business Journal (Anon, $1996 b$ ). Survey data are estimated to carry a \pm 5 percentage point range of error.

(2) The market is currently under development. Current market numbers do not reflect market potential.

(3) Numbers from different levels in the marketing channel reflect the 'value-added' nature of the product. The culture costs may only be a small fraction of the cost in the final product, where packaging, distribution, advertising, profit, and blending with other ingredients (e.g. cranberry extract, antioxidant vitamins, fructooligosaccharides and milk powders) add to the cost and the purchase price of the final product.

The available numbers on these markets are shown below. To put these numbers in context, Table 3 shows estimated sizes of related markets.

(1) SPINS Information Services, a company that follows the natural foods and dietary supplements markets, indicated a $9 \%$ increase in sales of dietary supplement probiotics in the American market during March 199697, as compared with that same period during 1995-96. This information comes from a survey of about $18 \%$ of distributor sales of natural foods in the USA.

(2) New Hope Natural Media reports on activity of about one-third of the natural products market in the USA at the retail outlet level. A survey of this portion of retailers reported sales (June 1995 to June 1996) of \$US72 million for probiotic products. About $5 \%$ of total dietary supplements sold were probiotic products. (New Hope cautions that these numbers cannot be extrapolated to the whole market.)

(3) The Nutrition Business Journal (Anon, 1996b) reported a survey of three North American manufacturers of probiotic cultures. Rhodia (formerly Rhone-Poulenc), Madison, WI, Chr. Hansen, Milwaukee, WI, and Rosell Institute, Montreal, Canada, are estimated to produce $70 \%$ of probiotic cultures for the North American market for both dairy and dietary supplements. These sources indicated that more cultures are sold to dairy markets than to dietary supplement markets, with about \$US1 million of culture going to the probiotic-containing fluid milk market.

(4) Retail cost of probiotic dietary supplements is estimated at about $2-10$ cents per billion $\left(10^{9}\right)$ cfu. A bottle of 100 capsules containing 1.5 billion cfu/capsule sells for about \$US12.

(5) No retail mark-up is apparent on yoghurt products containing probiotics compared to ones that do not contain them.

(6) The price premium on probiotic-containing fluid milks is about $10-30 \%$.

(7) Sales of spoonable yoghurt were up $10 \%$ in $1994.4 \%$ in 1995 and $3 \%$ in 1997 (A.C. Neilson, Northbrook, IL).

These data suggest that the American market for probiotic bacteria in dietary supplement markets, although small, is a profitable, growing market, but that growth of the market for probiotic-containing dairy products will not come without efforts to communicate information on probiotic bacteria.

\section{How are probiotic products promoted?}

Several factors contribute to the expansion of probiotic and other natural product markets.

(1) People would rather prevent than cure disease.

(2) People are more aware of the link between health and nutrition.

(3) People want to counteract the perceived increase of environmental hazards from pollution, pathogenic microbes and chemicals in air, water and food.

(4) Health-care costs are on the rise and nutraceuticals and functional foods provide a low-cost approach for maintaining health.

(5) The American population is ageing, increasing the population segment with health problems.

(6) Controlled scientific studies are providing support for efficacy of natural approaches (including probiotics) to maintaining health with few, if any, negative sideeffects.

Considering this atmosphere, it seems that it should be easy to make a marketing splash with a well-designed probiotic-containing product. 'Trillions of friendly bacteria 
Table 4. Examples of label statements for yogurts and dietary supplements containing probiotic bacteria

\begin{tabular}{|c|c|c|c|}
\hline $\begin{array}{l}\text { Product } \\
\text { type }\end{array}$ & Manufacturer & $\begin{array}{l}\text { Product name } \\
\text { (probiotic contents) }\end{array}$ & Label statement \\
\hline $\begin{array}{l}\text { Dietary } \\
\text { supplement }\end{array}$ & $\begin{array}{l}\text { Natural Factors, } \\
\text { Santa Barbara, CA }\end{array}$ & $\begin{array}{l}\text { L. acidophilus } \\
\text { and } B \text {. bifidum }\end{array}$ & '...to maintain healthy bacterial balance' \\
\hline $\begin{array}{l}\text { Dietary } \\
\text { supplement }\end{array}$ & $\begin{array}{l}\text { Natures Way } \\
\text { Products, } \\
\text { Springville, UT }\end{array}$ & $\begin{array}{l}\text { Premadophilus } \\
\text { Junior }\end{array}$ & $\begin{array}{l}\text { 'Contains specially selected strains of freeze } \\
\text { dried Lactobacillus casei subspecies } \\
\text { rhamnosus, Bifidobacterium adolescentis, } \\
\text { Bifidobacterium infantis, Lactobacillus } \\
\text { acidophilus in a neutral base of maltodextrin. } \\
\text { Enteric coated. Dairy free' }\end{array}$ \\
\hline $\begin{array}{l}\text { Dietary } \\
\text { supplement }\end{array}$ & $\begin{array}{l}\text { Futurebiotics, } \\
\text { Brattleboro, VT }\end{array}$ & $\begin{array}{l}\text { Longest living } \\
\text { acidophilus + }\end{array}$ & $\begin{array}{l}\text { 'Stays potent without refrigeration', 'Outside } \\
\text { North America, Lactobacillus rhamnosus is } \\
\text { even more highly regarded than acidophilus' }\end{array}$ \\
\hline Low-fat milk & $\begin{array}{l}\text { Land O'Lakes, } \\
\text { Minneapolis, MN }\end{array}$ & $\begin{array}{l}\text { Plus } 3 \text { milk } \\
\text { (L. acidophilus } \\
\text { Bifidobacteria } \\
\text { vitamin E) }\end{array}$ & $\begin{array}{l}\text { 'This natural inhabitant of the human } \\
\text { digestive system heips you efficiently digest } \\
\text { the foods you eat, and the milk you drink. } \\
\text { You were born with this culture, and your } \\
\text { system works best when there's a healthy } \\
\text { supply' } \\
\text { 'Another natural inhabitant of the human } \\
\text { digestive system, this culture helps to keep } \\
\text { your system operating the way nature } \\
\text { intended. Bifidus has also been with you } \\
\text { since birth, and it's important to maintain the } \\
\text { amount your body requires' } \\
\text { 'Let your body decide. Does your body have } \\
\text { sufficient vitamin E, Acidophilus, and Bifidus? } \\
\text { To find out for yourself, try the PLUS } 3 \\
\text { Wellness Test. Switch to delicious PLUS } 3 \\
\text { Lowfat milk and orange juice. Let your taste } \\
\text { buds and your body be your judge' }\end{array}$ \\
\hline Milk & $\begin{array}{l}\text { Robinson Dairy, } \\
\text { Denver, CO }\end{array}$ & $\begin{array}{l}1 / 2 \% \text { PLUS } \\
\text { (L. acidophilus } \\
\text { and Bifidobacteria) }\end{array}$ & $\begin{array}{l}\text { 'These a/B cultures may help keep your } \\
\text { digestive system healthy and balanced. } \\
1 / 2 \% \text { PLUS may even help you digest foods } \\
\text { you cannot now eat comfortably' }\end{array}$ \\
\hline Yoghurt & $\begin{array}{l}\text { Nancy's, } \\
\text { Eugene, OR }\end{array}$ & Low-fat Yoghurt & $\begin{array}{l}\text { 'Nancy's yoghurt is made from the finest } \\
\text { ingredients and cultured with } L \text {. acidophilus } \\
\text { and } B \text {. bifidum to assist in lactose digestion } \\
\text { and maintain a healthy and balanced } \\
\text { intestinal system' }\end{array}$ \\
\hline
\end{tabular}

live here' is a sign painted above a refrigerated case containing dietary supplement probiotic bacteria in a Denver-area natural foods grocery store. This is clearly an effort by management to communicate a positive image of probiotics. However, this is a challenging task. Probioticcontaining products are difficult to promote for several reasons. First, there are legal restrictions on labelling food products with statements related to promotion of health. Claims for the prevention, cure or mitigation of disease are limited to the eleven which have received official Food and Drug Administration (FDA) approval. A claim about probiotics is not one of them. Structure/function claims (claims which relate a food to the maintenance of health rather than the mitigation of disease) are the domain of dietary supplements [a category of foods specifically defined in the Dietary Supplement Health and Education Act (1994)], not foods. Although a cleverly packaged yoghurt product might be legally marketed as a dietary supplement if labelling requirements are met (labelled as a dietary supplement, not represented as a conventional food or as a sole item of a meal or of the diet, and in dosage form), this approach may invite FDA scrutiny. Second. it is difficult to communicate the benefits of probiotic bacteria to consumers. People do not know what Lactobacillus and bifidobacteria are. Consumers already have a negative perception of bacteria that may be hard to change. Third, there is a lack of scientific consensus on the benefits of probiotic cultures, especially when considering specific effects. Although a scientific basis for probiotic function can be put forward, supported by a variety of clinical and mechanistic studies, extrapolation of that information to a specific application is not possible. For example, what do positive results from a clinical trial done on prevention of rotavirus diarrhoea in a hospitalized paediatric population mean for a healthy adult population? How can we know the effect on the health of the general population of a probiotic culture shown to increase levels of activated macrophages in laboratory rats? Even though many probiotic-containing products are on the market, difficult questions regarding these products often do not have answers. What is an effective dose of a specific 
Table 5. Strain-specific attributes of probiotic microbes

\begin{tabular}{|c|c|}
\hline In vitro strain characteristics & $\begin{array}{l}\text { Taxonomy } \\
\text { Source } \\
\text { Purity } \\
\text { Fermentation characteristics }\end{array}$ \\
\hline Research results on health effects & $\begin{array}{l}\text { In vitro studies } \\
\text { Animal studies } \\
\text { Human clinical studies }\end{array}$ \\
\hline \multicolumn{2}{|r|}{ 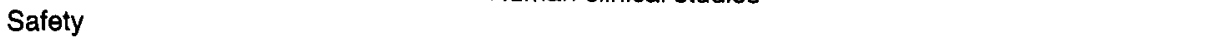 } \\
\hline Pharmacology & $\begin{array}{l}\text { Target for product: general population v. specific at-risk group } \\
\text { What substantiated claims can be made }\end{array}$ \\
\hline Product information & $\begin{array}{l}\text { Food or dietary supplement } \\
\text { Format: dried, capsule, tablet, liquid } \\
\text { Additional 'bioactive' components } \\
\text { Storage stability } \\
\text { Viable counts at consumption } \\
\text { Cost }\end{array}$ \\
\hline
\end{tabular}

strain? Who will benefit from use of the probiotic, and to what extent? Is viability essential for the effect? Which genera, species or strains are effective (strain-specificity of clinical effects is assumed for most targets by the scientific community)?

The above limitations notwithstanding, labels on probiotic products must tell the consumer something about the product, and this effort to communicate the benefits of a product must be done in an ethical manner (Giese \& Katz, 1997). Table 4 is a survey of some of those commercial labels. In the case of most commercial yoghurts in the USA, one needs to look hard to find a comment on the presence of the probiotic bacteria. Brands of yoghurt marketed more in the natural foods shops than in mainstream groceries tend to make a more prominent statement of probiotic content, but few yoghurts make any statement as to why the bacteria are present.

\section{Sizing up probiotic bacteria}

Once convinced that probiotic bacteria are worth considering for a new product, perhaps the most difficult task is choice of a strain or strains for the product. There are many strain-specific attributes of probiotic bacteria (Table 5). Some commercially available strains and probiotic-containing products available worldwide (Table 6) demonstrate the range of probiotic bacteria from which manufacturers and consumers must choose. It is wise, however, to proceed in this endeavour with caution. When reviewing data presented as evidence of clinical efficacy, consider the following:

(1) Avoid simplistic conclusions from a complex study.

(2) Avoid recommendations based on a single study.

(3) Be suspect of non-peer reviewed studies.

(4) Be suspect of recommendations that extrapolate from one small subgroup to the population as a whole.

(5) Recognize the difference between:

(a) statistical and substantive significance; and

(b) correlation and cause and effect.

(6) Clinical studies should be:

(a) placebo-controlled; and

(b) conducted with an adequate number of subjects to be biologically significant.

\section{Future of probiotics}

Interest in probiotics is likely to increase in the USA, following the trends of other products that have a healthy image. Furthermore, companies will probably stretch product development groups to move beyond yoghurt and milk into broader food categories. Products like energy bars, juices, cereals, cheeses with probiotics and perhaps other health-enhancing ingredients will emerge. The future will bring increased understanding of the type and magnitude of probiotics' benefits and this information will be strainspecific. Not all probiotic products are equal, and research will differentiate them.

Table 6. Some commercially available probiotic strains and products

\begin{tabular}{ll}
\hline Strain & \multicolumn{1}{c}{ Manufacturer } \\
\hline Lactobacillus acidophilus NCFM & Rhone-Poulenc (Rhodia), Wisconsin, USA \\
Lactobacillus rhamnosus GG & Valio Dairies, Finland \\
Lactobacillus reuteri 1063 & BioGaia, North Carolina, USA \\
Bifodobacterium longum BB536 & Morinaga Milk Industries, Japan \\
Lactobacillus plantarum 299V & ProViva, Finland \\
Lactobacillus casei YIT9018 (Shirota) & Yakult, Japan \\
Lactobacillus johnsonii LJ-1 & Nestlé, Switzerland \\
\hline
\end{tabular}




\section{References}

Anon (1996a) Nutraceutical debate to define industry future. Nutrition Business Journal 1, 1-3.

Anon (1996b) Leaders stake out market for cultures. Nutrition Business Journal 1, 4-5.

Anon (1997) Another world giant signs up for LGG. Valio LTD Newsletter 'Milkshake'. Valio Ltd, Helsinki, Finland.

Charteris WP, Kelly PM, Morelli L \& Collins JK (1997) Selective detection, enumeration and identification of potentially probiotic Lactobacillus and Bifidobacterium species in mixed bacterial populations. International Journal of Food Microbiology 35, 127.

Dave, RI \& Shah NP (1997a) Viability of yoghurt and probiotic bacteria in yoghurts made from commercial starter cultures. International Dairy Journal 7, 31-41.

Dave RI \& Shah NP (1997b) Effectiveness of ascorbic acid as an oxygen scavenger in improving viability of probiotic bacteria in yoghurts made with commercial starter cultures. International Dairy Journal 7, 435-443.

Dave RI \& Shah NP (1997c) Effect of cysteine on the viability of yoghurt and probiotic bacteria in yoghurts made with commercial starter cultures. International Dairy Journal 7, 537-545.

Giese J \& Katz F (1997) Ethical marketing of functional foods. Food Technology 51, 58-61.

Gorski D (1998) Kefir and colostrum beverage. Dairy Foods 99 , 45.

Greenberg PD \& Cello JP (1996) Treatment of severe diarrhea caused by Cryptosporidium parvum with oral bovine immunoglobulin concentrate in patients with AIDS. Journal of AIDS and Human Retrovirology 13, 348-354.

Hughes VL \& Hillier SL (1990) Microbiologic characteristics of Lactobacillus products used for colonization of the vagina. Obstetrics and Gynecology 75, 244-248.

Kailasapathy K \& Rybka S (1997) L. acidophilus and
Bifidobacterium spp. - their therapeutic potential and survival in yogurt. Australian Journal of Dairy Technology 52, 28-35.

Klaver FAM, Kingma F \& Weerkamp AH (1993) Growth and survival of bifidobacteria in milk. Netherlands Milk and Dairy Journal 47, 151-164.

McFarland LV \& Elmer GW (1997) Pharmaceutical probiotics for the treatment of anaerobic and other infections. Anaerobe. 3, $73-78$.

Onggo I \& Fleet GH (1994) Media for the isolation and enumeration of lactic acid bacteria from yoghurts. Australian Journal of Dairy Technology 48, 89-92.

Rybka S \& Fleet GH (1997) Populations of Lactobacillus delbrueckii ssp. bulgaricus, Streptococcus thermophilus, Lactobacillus acidophilus and Bifidobacterium species in Australian yoghurts. Food Australia 49, 471-475.

Salvadori BB (1997) Dairy starter cultures of lactic acid bacteria (LA). Standard of identity. Annex A. Guidelines for Methods of Analyses. IDF Standard 149A, International Dairy Federation, Brussels, Belgium.

Sanders ME (1996) Probiotic cultures and human health. In Germfree Life and its Ramifications [Hashimoto $\mathrm{K}$, editor]. XII ISG Puglishing Committee, Shiozawa, Japan.

Sanders ME, Walker DC, Walker KM, Aoyama K \& Klaenhammer TR (1996) Performance of commercial cultures in fluid milk applications. Journal of Dairy Science 79, 943-955.

Shah NP (1997) Isolation and enumeration of bifidobacteria in fermented milk products - a review. Milchwissenschaft-Milk Science International 52, 72-76.

Stephan W, Dichtelmuller H \& Lissner R (1990) Antibodies from colostrum in oral immunotherapy. Journal of Clinical Chemistry and Clinical Biochemistry 28, 19-23.

Wrick KL (1995) Consumer issues and expectations for functional foods. Critical Reviews in Food Science and Nutrition 35,167173. 